\title{
PEREGRINOS EN EL INFIERNO. ENEAS Y DANTE
}

\author{
Beatriz Ginés F uster \\ Universitat de València
}

Resumen: Las similitudes entre el inframundo de la Eneida y el infierno de La Divina Comedia es un hecho casi incuestionable. La influencia de Virgilio en Dante es más que palpable en toda la obra del florentino. En este artículo nos centraremos en recopilar y demostrar dicho argumento centrándonos en los conceptos de inframundo e infierno y como Dante se sirve de la obra de Virgilio, entre otros, para diseñar el infierno de La Divina Comedia.

Palabras clave: Inframundo, infierno, Eneas, Virgilio, Dante, influencia.

\section{Pellegrini nell'inferno. Enea e Dante}

Riassunto: Le somiglianze tra gli inferí dell'Eneide e l'inferno della Divina Commedia sono un fatto quasi indiscutibile. L'influenza di Virgilio è più che evidente in tutta l'opera di Dante. Questo articolo vuole riepilogare e dimostrare tale tesi concentrandosi sui concetti di inferí e inferno e como Dante si serve dell'opera di Virgilio, tra gli altri, per disegnare l'inferno della Divina Commedia.

Parole chiavi: Inferí, inferno, Enea, Virgilio, Dante, influenza.

Desde la antigüedad, el infierno y la idea del más allá ha estado vinculado al pensamiento colectivo de las civilizaciones. Aunque es cierto que el concepto ha evolucionado y se ha adaptado según las épocas. Las primeras noticias que conocemos sobre el infierno están despojadas del concepto de castigo y muestran lugares de permanencia de las almas de los difuntos.

Pero el objetivo de este trabajo no es realizar una evolución descriptiva sobre los distintos infiernos, sino comparar las similitudes entre el inframundo de la Eneida y el infierno de La Divina Commedia. Para ello comenzaremos repasando los conceptos del más allá que se tenían en la Roma del recién nacido Imperio Romano, y en la Italia del siglo XIV.

A nuestro juicio, antes de entrar en materia se debe realizar una puntualización para la mejor comprensión del texto. Los conceptos "inframundo" e "infierno" no deben de utilizarse como sinónimos, puesto que existen diferencias que debemos destacar. El "inframundo", según la tradición clásica, acoge todos los reinos donde van a parar las almas tras la muerte. Entre estos reinos destacan los Campos Elíseos, donde habitan las almas virtuosas o heroicas, o el Tártaro donde los malvados eran castigados eternamente. Sin embargo, cuando hablemos de "infierno", hay que entender como tal una parte del más allá, el lugar donde van a parar las almas que, según el código moral cristiano, no han tenido un buen comportamiento y por lo tanto su destino es el de sufrir tormentos para toda

Data de recepció: 18 de juny de 2014 / Data d'acceptació: 26 de gener de 2015. 
la eternidad. A grandes rasgos el infierno es equivalente al Tártaro griego, pero no al inframundo. Así pues se debe aplicar la palabra "inframundo" para hacer referencia al reino de los muertos recogido en las fuentes clásicas, y más concretamente en la Eneida de Virgilio; y el concepto "infierno" para aludir al espacio donde moran las almas de los malvados o no bautizados en La Divina Commedia de Dante Alighieri.

Ambos conceptos establecen un complejo sistema de ordenación en el que cada alma tiene un lugar asignado dependiendo de su comportamiento en vida y siguiendo un código moral ligado a la cultura y religión de la época. El inframundo de la Eneida es una herencia de la civilización griega, nombrado por primera vez en la Ilíada de Homero. No obstante fue Virgilio quien le dio una importancia mayor al describirlo con gran pericia.

\section{INFRAMUNDO VIRGILIANO}

Según Virgilio, la entrada al inframundo está situada en el actual lago Fusaro (Campania, Italia), conocido en la antigüedad como Acherusia Palus, un pantano infernal formado por el río Aqueronte. Dicha entrada está descrita como una caverna rodeada de agua nauseabunda. Una vez pasado el umbral, se debe descender hacia la oscuridad para llegar al vestíbulo donde se encuentran las Dolencias amarillas y la triste Vejez y el torpe Miedo, la Hambre, a mal hacer persuadidora, la infame, desechada y vil Pobreza; rostros de ver terribles y espantosos: el Trabajo, la Muerte y su pariente el Sueño, los ilícitos Placeres del alma. En la frontera umbral reside la funesta, sangrienta y cruda Guerra; allí tienen las Furias sus palacios de durísimo hierro fabricados. La perversa Discordia está a par de ellas, de víboras crinada, que con nudo de toca, en sangre tinta, coge y prende. Un grande y sombroso olmo está plantado en medio del zaguán, que a todas partes prolijos ramos tiende y viejos brazos: en aqueste árbol dice el rudo vulgo que tienen nido los Ensueños vanos y a cuantas hojas tiene están pegados... (Virgilio, 2000, p. 198). Una gran cantidad de monstruos como los Centauros, Scilas, la Hidra, la Quimera, las Gorgonas y las Harpías, custodian dicho zaguán. Tras pasar este trago, y siguiendo un camino se llega a la ribera del Aqueronte, descrito como un piélago turbio y pestilente. En esta ribera moran las almas de los que no pueden pagar al barquero Caronte. En la orilla opuesta reina el temible Cancerbero que custodia la puerta del inframundo. A continuación existe un espacio donde se escuchan mil vivos gritos y gran llanto que las almas hacían de tiernos niños a quien el negro día de la Muerte, ayunos de gustosa y dulce vida, arrebató de la sabrosa teta y soterró en la triste sepultura. A par de éstos están los que murieron con falso testimonio condenados (Virgilio, 2000, p. 205). Es en este espacio donde se encuentra Minos como juez e inquisidor de los delitos. Es él quien decide el destino de las almas. Muy cerca se encuentran los suicidas encadenados de por vida y no muy lejos el llamado Campo de los lamentos o Llorosos campos, donde están los miserables a quien del duro amor la brava llama consumió e hizo el corazón ceniza. Una ancha selva de sombrosos mirtos los cubre y cerca en torno y nunca pierden, aun con morir, las ansias amorosas (Virgilio, 2000, p. 206). Pasadas estas almas tienen hogar las de los guerreros ilustres fallecidos en combate.

Hasta aquí el inframundo no es un lugar de torturas, tal y como nos recuerda George Minois en Historia de los Infiernos (Minois, 1994, p. 70), sino una continuación de los sufrimientos terrenos, donde las almas se lamentan de sus desdichas. Es justo a partir de una bifurcación de caminos cuando todo comienza a adquirir un ambiente mucho más serio. 
A un lado está el sendero que conduce al Elíseo donde moran las almas de los bienaventurados; mientras que el otro conduce al Tártaro, hogar de los tormentos. Es en el Tártaro donde los malvados en vida sufren el castigo merecido dentro de una fortaleza de hierro con una gigantesca puerta y una triple muralla rodeada por un río en llamas. Guardando la entrada se encuentra una de las furias, Tisífone.

Desde luego, las descripciones de Virgilio difieren en algunos aspectos de las de otros escritores como Hesíodo u Homero, pero fue la descripción que más caló en la sociedad y la cultura futura. Sin embargo existe una mezcla de dos conceptos que posteriormente estarán muy bien definidos: el infierno y el purgatorio. Resulta evidente que la tipología en la que podemos englobar el inframundo virgiliano, es la de un infierno provisional, puesto que cuando las almas quedan purificadas, pasan directamente al Elíseo, donde moran mil años mientras que beben el olvido en la fuente Lete, y se reencarnan en otro cuerpo. No supone un infierno absoluto, puesto que le faltaría el concepto de eternidad que posteriormente añadió el cristianismo (Minois, 1994, p. 74).

\section{INFIERNO DANTESCO}

Por lo que respecta a La Divina Commedia resulta muy clara la influencia que Virgilio ejerció sobre Dante Alighieri y su obra, tanto es así que lo nombró su guía en el infierno y purgatorio.

El infierno dantesco es la combinación justa entre el infierno popular extraído de leyendas y relatos de los orígenes del cristianismo y del Sehol hebreo; y el infierno intelectual y teológico propiamente dicho. Así pues, Dante realiza una ordenación de la topografía infernal, que hasta ahora había sido algo caótica y cambiante. Establece un sistema de ordenación basado en un código moral y racional, en el cual las faltas cometidas tienen un castigo relacionado con la naturaleza del pecado. El poeta diseña una estructura con forma de embudo dividida en nueve círculos concéntricos donde se castigan los siete pecados capitales.

La novedad principal de la ordenación moral del infierno dantesco reside en la independencia que le da al purgatorio separando así las faltas cometidas, con las faltas cometidas y arrepentidas. En el caso del infierno, los pecadores nunca verán la luz, de hecho están privados de la visión divina, y jamás podrán escapar o redimirse. Por lo que respecta al purgatorio, las almas de los pecadores sufrirán, casi igual que en el infierno, pero solamente durante un periodo determinado, dependiendo del pecado, porque posteriormente irán a parar al paraíso.

Si pasamos brevemente a desarrollar la estructura del infierno, debemos hablar en primer lugar del vestíbulo o anteinfierno donde morarán permanentemente las almas de los pusilánimes y los indecisos. A partir de aquí se entra en el infierno propiamente dicho y dividido en dos partes. La primera de ellas, el infierno superior, donde se encuentran los pecadores menos graves puesto que la falta cometida se caracteriza por la incontinencia. Tras haber cruzado el río Aqueronte con la ayuda del barquero Caronte, se entra en el círculo primero conocido como Limbo, donde moran las almas de los niños no bautizados, paganos e infieles. En este caso no importa que una persona haya tenido una conducta buena en vida, puesto que si no gozó del sacramento del bautismo no puede obtener la gracia divina. En el segundo círculo moran los lujuriosos o los que murieron por amor, el guardián de 
este lugar es Minos. Por lo que respecta al tercer círculo o tercera vuelta el Cancerbero es el protagonista principal de este espacio donde habitan los glotones. En el cuarto círculo están los avaros y derrochadores; y por último en el quinto círculo los iracundos.

Si bien hemos aludido anteriormente a dos partes fundamentales en las que está dividido el infierno, la segunda de ellas es la que engloba del sexto al noveno círculo. Es conocido como infierno inferior. En esta zona se encuentras las almas de los pecadores cuya falta es más grave. En el sexto círculo están los herejes, en el séptimo los violentos divididos en tres grupos, a saber violentos contra otros, contra sí mismos, contra Dios, la naturaleza y el arte; en el octavo círculo encontramos a los fraudulentos repartidos en diez fosas: proxenetas y embaucadores, aduladores, simoníacos, adivinos y magos, malversadores y estafadores, hipócritas, ladrones, malos consejeros, sembradores de discordia y por último falsificadores. En el noveno se hallan los traidores divididos en tres subgrupos: traidores a la familia, a la patria y a los huéspedes. Es en este último tramo donde encontramos a Lucifer.

Desde luego, resulta evidente la combinación entre el infierno popular y el teológico diseñado por Dante y que casa a la perfección. El hecho de que La Divina Commedia estuviese escrita en florentino o "lengua vulgar" y no en latín permitió su difusión muy rápidamente y a su vez se consiguió crear una imagen común del infierno.

\section{PEREGRINOS ANTERIORES}

Probablemente desde los orígenes de los tiempos, la humanidad no ha dejado de preguntarse cómo podía ser el más allá. Quizá por ello, en todas las culturas se ha intentado explicar o dar una visión de cómo podía ser este lugar. Así pues el descenso a los infiernos ha sido un tema muy recurrente en la literatura universal.

Ya desde el conocido mito sumerio de Gilgamesh en el que su querido amigo Enkidú le narró su bajada a la mansión de Irkalla (1997, Tablilla VII) o Casa de las Tinieblas, pasando por otro mito mesopotámico según el cual la diosa Ishtar descendió al Kurnugi (Vidal, 2008, p. 1501). Pero, donde más ejemplos encontramos es en el mundo grecorromano donde Orfeo, Ulises, Teseo, Hércules o Pirítoo descendieron al inframundo. La mayoría de estos personajes fueron héroes y generalmente emprendían este viaje movidos por el desconsuelo ante la pérdida de un ser querido, o bien, por la necesidad de consultar a algún alma el futuro que le deparaba. Algunos de ellos como Pirítoo se quedaron encerrados en vida para toda la eternidad, pero la mayoría consiguieron escapar.

Por lo que respecta al mundo cristiano encontramos el ejemplo más destacado de descenso a los infiernos en Cristo, cuando viajó hasta el Limbo para salvar las almas de los patriarcas y los profetas del Antiguo Testamento que no habían disfrutado del sacramento del bautismo por haber nacido en una época anterior (Biblia, Hechos, 2.31, 1972, p. 1306).

Ciertamente existen una gran cantidad de relatos de descenso a los infiernos y descripciones del mismo. Pese a todo, ha sido Dante en La Divina Commedia quien mejor ha sabido relatar este viaje de ultratumba aprovechando para describir de forma muy exhaustiva la topografía del mundo infernal. Para la realización de tal magna labor, como hemos dicho anteriormente, se valió de muchas influencias, pero la que sin duda más destaca es la descripción del inframundo de la Eneida. Pasemos por lo tanto al análisis de ambas obras y a la exposición de similitudes entre infierno dantesco e inframundo virgiliano. 


\section{PERSONAJES PRINCIPALES Y GUÍAS}

Tanto las narraciones como los personajes de la Eneida y La Divina Commedia son muy diferentes entre sí. Por un lado la Eneida fue escrita por el poeta Publio Virgilio Marón en el 19 a.C y narra los avatares de Eneas, un príncipe que huyó de la ciudad de Troya tras ser saqueada y quemada por los aqueos. Después de sufrir numerosos incidentes acabó por instalarse en la costa del Lacio, concretamente en el territorio gobernado por el rey Latino, donde tomó como esposa a la hija de este, Lavinia. Generaciones después nacieron Rómulo y Remo, fundadores de Roma. Entre las muchas dificultades que Eneas encontró en el camino destaca el viaje al inframundo en busca de la ayuda de su padre Anquises.

Por otro lado La Divina Commedia fue escrita por Dante entre 1303 y 1321. Aquí el autor narra un viaje imaginario, protagonizado por él mismo, a los tres reinos de los muertos: infierno, purgatorio y paraíso.

Mientras que Eneas es descrito por Virgilio como un héroe troyano, hijo de la diosa Afrodita y del mortal Anquises, que no muestra debilidad ante las distintas vicisitudes a las que se ve sometido, Dante no tiene ningún reparo en narrar los miedos y temores que siente en el viaje al más allá. No se presenta en ningún momento como un héroe, sino como un hombre mortal. El carácter de ambos personajes puede que esté condicionado en mayor medida por los motivos que les mueven a realizarlo. Eneas tenía como objetivo principal encontrar a su padre Anquises, que había fallecido poco después de huir de Troya. Una noche, Anquises se le apareció a su hijo en sueños dándole cierta información sobre el futuro de este, sin embargo le pedía que acudiese al inframundo para detallarle los pormenores (Virgilio, 2000, pp. 177-178). La vida de Eneas y del resto de sus hombres dependía de su decisión de descender al Hades para recopilar los detalles de su futuro. Para dicho fin, su padre le había aconsejado encontrar primero a la Sibila de Cumas para que le guiase. Una vez encontrada, esta solicitó a Eneas el sacrificio de matar sin dilación siete becerros de la manada entera los mayores, y luego siete ovejas las mejores (Virgilio, 2000 , p. 187). Tras esto y algún que otro rito más, comenzó el descenso al inframundo.

El caso de Dante es totalmente diferente. En un principio, el poeta no tenía la intención de realizar tal viaje, sino que en un cierto momento de su vida, se encuentra en esa situación. Los primeros versos de La Divina Commedia lo demuestran: Hallábame a la mitad del camino de nuestra vida, cuando me vi en medio de una oscura selva, fuera de todo camino recto (Alighieri, 2003, p. 35). Al no elegir su destino, el temor y desconcierto que siente es totalmente comprensible, con lo cual la valentía de Eneas no tiene razón de ser en Dante, puesto que la situación le viene impuesta. Cuando el poeta dice que se ha apartado de todo camino recto, hace alusión a la pecaminosa vida que había emprendido tras la muerte de Beatrice Portinari, musa y guía del poeta en el paraíso. Para purgar todos sus pecados, Dante debe realizar un viaje por el infierno, purgatorio y finalmente llegar al paraíso donde podrá obtener la mayor de las recompensas: la contemplación divina. A diferencia de Eneas, que va en busca de la Sibila para que le oriente en el inframundo, Dante solo tiene que esperar unos minutos hasta que aparece Virgilio que se le presenta como su guía y mentor en lugares donde oirás el chillar desesperado, verás doliente las antiguas sombras gritando todas la segunda muerte (Alighieri, 2013, p. 88).

En ambas obras, los protagonistas no pueden andar solos por el reino de los muertos, ya que no son almas, sino que todavía pertenecen al mundo de los vivos. Los guías, tanto 
la Sibila como Virgilio, serán los encargados del bienestar de los "peregrinos” y responsables de que alcancen sus objetivos. Son dos personajes muy diferentes entre sí, pero que cumplen perfectamente su objetivo en la narración.

En el caso de la Sibila de Cumas, o también llamada Sibila Cumana, es el dios Apolo quien le infunde el don de las visiones. Era considerada una de las profetisas más importantes de la antigüedad y al pasar la mayor parte de su vida en Cumas le fue otorgado ese nombre. Virgilio, por otro lado, no solo fue el escritor de la Eneida, sino que lo encontramos como protagonista de La Divina Commedia. Él será el encargado de guiar a Dante por el infierno y el purgatorio, y de protegerlo de los males que le acechan.

El florentino sentía una gran admiración por Virgilio y conocía a la perfección su obra, con lo cual no debe extrañar que Dante (escritor) elija a Virgilio como guía de Dante (protagonista). En el canto I del infierno se ven muy claramente las intenciones del florentino cuando reconoce la sombra de Virgilio: ¿Tú eres Virgilio, pues, y aquella fuente que destila de hablar caudal tan largo?...Eres tú mi maestro, eres mi autor, el único eres tú de quien tomé el bello estilo por el cual me honran (Alighieri, 2013, p. 87). No se puede concebir mejor guía para Dante; por una parte era poeta, al igual que él, y además estaba destinado a habitar en el Limbo junto con el resto de poetas clásicos lo que le hacía perfecto conocedor del infierno (según Dante, en el Limbo moran las almas de los no bautizados y los paganos virtuosos, que pese a haber llevado una vida correcta no gozaron del sacramento del bautismo, con lo cual muchos poetas clásicos están en esa zona neutral, pero sin disfrutar de la visión de Dios). Asimismo, Dante se considera un alumno de Virgilio, es más, lo llama continuamente "maestro".

\section{GEOGRAFÍA INFERNAL Y PERSONAJES SECUNDARIOS}

Mientras que en la Eneida el inframundo comprende solo una muy pequeña parte de la obra, en La Divina Commedia, el infierno es una tercera parte del poema. Así pues es mucho más sencillo para Dante describir con mayor pericia toda la geografía del infierno. A pesar de que en cada época el infierno o inframundo está descrito de una u otra forma existen unas pautas o elementos comunes que se repiten en el inframundo virgiliano y el infierno dantesco.

Dante puso mucha atención a la descripción de espacios a lo largo de toda la obra, y gracias a ello, muchos artistas no han tenido ninguna dificultad de representar una y otra vez a lo largo de los siglos los mapas del infierno, purgatorio o paraíso. Quizás una de las imágenes más representativas del infierno dantesco sea el mapa que realizó Sandro Botticelli para una de sus dos series de ilustraciones que acompañaban al poema. Botticelli conocía a la perfección el texto de Dante y eso lo supo plasmar en esta imagen donde si se mira con atención se pueden ver desde los ríos y lagunas que plagan el infierno hasta las murallas de la ciudad de Dite (Figura 1).

El infierno de la Commedia está concebido como un inmenso embudo, tal y como se puede observar en la ilustración, donde cada círculo se corresponde con un pecado; conforme se estrecha la estructura, el pecado es mayor. La entrada está situada bajo el Monte Calvario donde fue crucificado Cristo. Las descripciones del inframundo clásico son más escuetas y no se centran tanto en la estructura de conjunto sino en los detalles, en consecuencia no conocemos con exactitud su disposición exacta en la Eneida. 


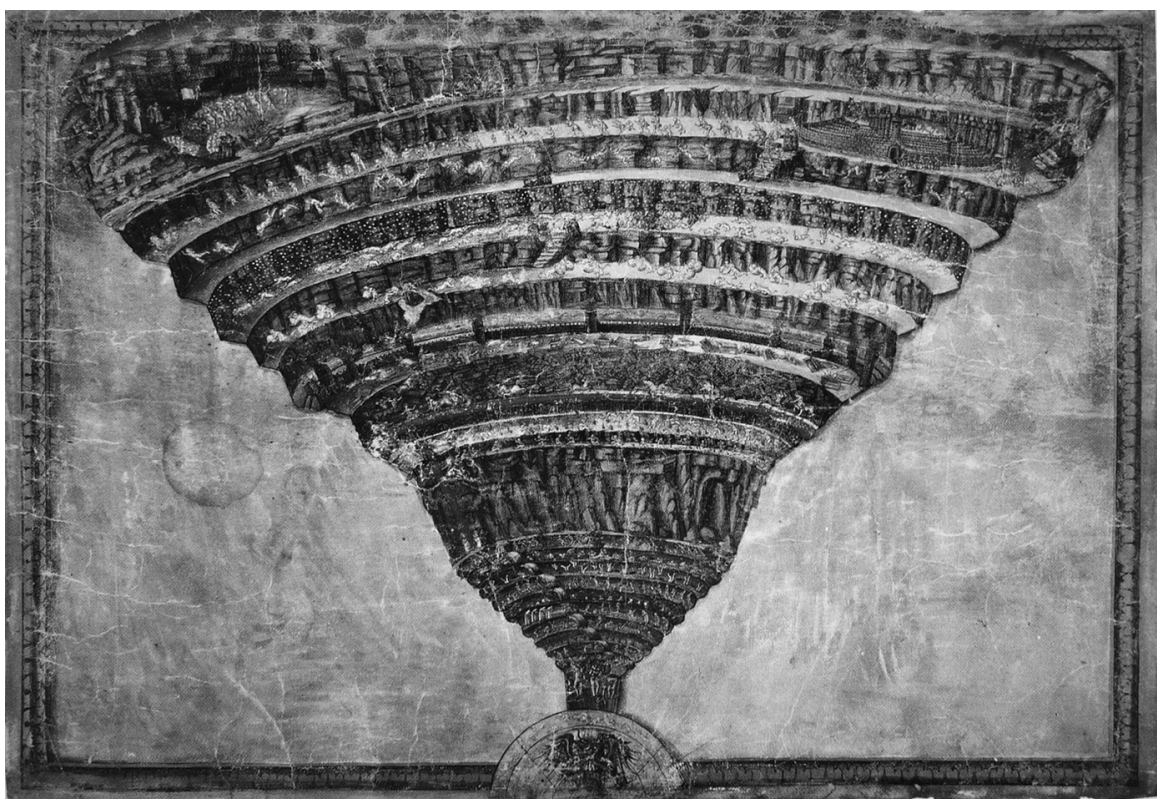

Figura 1. Mapa del Infierno. Sandro Botticelli. 1480-1495. Imagen obtenida de http:// www. worldofdante.org/ consultada el día 10 de junio de 2014.

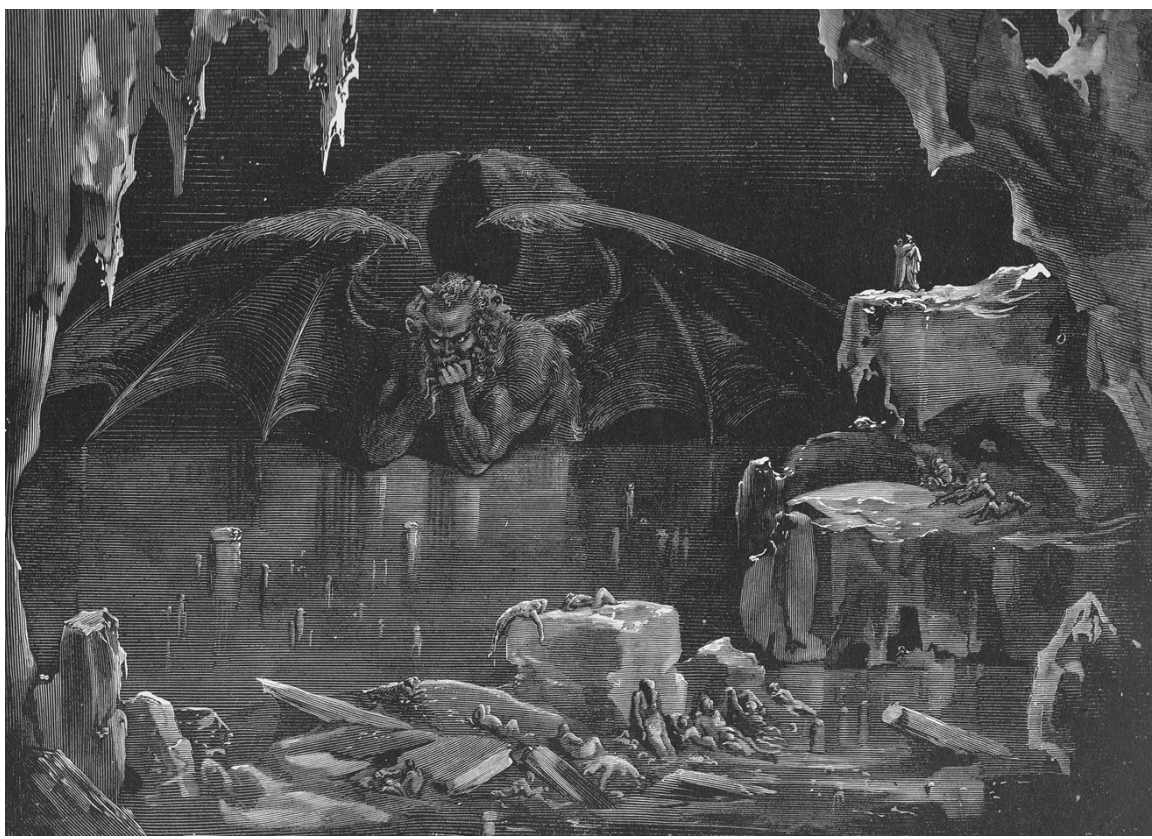

Figura 2. Infierno, canto XXXIV, Lucifer. Gustave Doré. 1832. 
El zaguán del infierno - Tanto Eneas como Dante, en el momento en que descienden al reino de los muertos, encuentran una foresta oscura que se corresponde con la antesala del inframundo e infierno respectivamente. Ambos personajes quedan sorprendidos de los gritos de dolor que se escuchan en el interior. En el caso de la Eneida son llantos de recién nacidos, ya que a esa foresta están destinados los niños fallecidos al poco de nacer. Esto nos puede llevar a confusión, ya que en La Divina Commedia, las almas de los recién nacidos habitan en el Limbo, no por haber pecado, sino por haber fallecido sin haber sido bautizados. La "selva oscura" descrita por Dante está habitada por tres fieras, que han tenido diversas interpretaciones por parte de la crítica, aunque la teoría que más fuerza tiene es que la selva alude claramente a una situación de alejamiento de la fe por parte de nuestro protagonista y por ello ha de comenzar el viaje de purificación desde lo más bajo del pecado.

Una vez pasada la foresta, tanto Eneas como Dante se encuentran de lleno con el río Aqueronte, descrito como uno de los principales ríos infernales en La Divina Commedia, pero en la Eneida descrito como una ciénaga pestilente. Para poder entrar en el inframundo/infierno propiamente dicho, las almas deben subir en la barca de Caronte y pagarle un óvolo para que les lleve a la otra orilla. La figura del barquero también es común en ambas obras. Según la Eneida, es guarda de este vado y triste paso el terrible Carón, barquero horrendo, de moho y mugre y suciedad cubierto. Cáele del yerto rostro un monte espeso de barba cana, inculta, sucia y hórrida; de los fogosos ojos echa llamas; trae una vil y andrajosa capa en los desnudos hombros anudada, Libro VII, vv. 297-300 (Virgilio, 2000, p. 199). Dante lo describe de forma muy parecida: Contemplamos de un vote la arribada, con un viejo de antiguo y blanco pelo... cuyos ojos circunda un fuego horrible, Infierno, canto III, vv. 82-86 (Alighieri, 2003, pp. 47-48).

Ambos relatos coinciden en la descripción de Caronte como un anciano con espesa barba cana y ojos llameantes. También es similar la forma en la que los protagonistas describen a un Caronte que les increpa al querer cruzar el río estando todavía vivos. Por supuesto, son los guías quienes aplacarán su ira y le convencerán de dejarles pasar. Caronte ya era representado en las tumbas etruscas como un demonio alado, con cabello de serpiente y portando un mazo en la mano. Posiblemente, por ello se ha supuesto que el Caronte etrusco acababa con la vida de los moribundos y era llamado "genio de la muerte" (Bosco, 1984, p. 847, v. 2). A Caronte se le representa como un personaje malhumorado y reticente a cruzar con la barca el Aqueronte. Con Teseo y Piritoo hizo una excepción, pero tiempo después cuando Hércules quiso hacer lo mismo se negó. Finalmente no tuvo más remedio que ceder ante la brutal paliza que le propinó.

Otro de los elementos geográficos más importantes que figura en ambas obras es el llamado Cocito. Virgilio imagina el Cocito como un río muy cercano al Flegetonte ${ }^{1}$, donde están las almas que no pueden pagar a Caronte. Sus aguas están compuestas por las lágrimas de los pecadores que tuvieron una mala conducta en vida (Grimal, 1981, p. 112). En la tradición griega el Cocito era el elemento geográfico que delimitaba la frontera entre el reino de los vivos y el de los muertos ${ }^{2}$.

No obstante en La Divina Commedia, el Cocito era un lago de agua helada situado en el noveno círculo del infierno, donde pagan por sus pecados los traidores (Bosco, 1983, p. 993, v. 3). Según Dante, el mayor de todos los pecados es la traición. El Cocito aparece dividido

\footnotetext{
1 Río compuesto de fuego que transcurre por el Hades y es afluente del Aqueronte.

2 El Cocito era también un afluente del Aqueronte y en ocasiones se confunden.
} 
en cuatro partes: la Caína, la Antenora, la Tolomea y la Judeca; cada una de ellas lleva el nombre de un traidor. En la Caína se encuentran las almas que traicionaron a sus familiares, por ello el nombre proviene de Caín, que según la Biblia mató a su hermano Abel. Las almas de los pecadores de esta zona están enterradas en el agua helada hasta el cuello. La Antenora recibe este nombre por el consejero del rey Príamo, Antenor, que traicionó a los troyanos. Con lo cual Dante coloca en este espacio a los traidores de la propia patria, enterrándolos en el hielo de cintura hacia abajo. La tercera de las zonas en las que está divido el Cocito es la Tolomea donde cumplen su penitencia los traidores a los huéspedes que permanecen inmóviles en el hielo por la parte posterior del cuerpo. El nombre proviene de un gobernante de Jericó llamado Tolomeo que asesinó a sus huéspedes (Biblia, Macabeos I, 16, 16). Finalmente encontramos la Judeca, la peor zona del infierno donde moran los pecadores acusados de traicionar a sus amos o benefactores. Según Dante, es uno de los pecados más graves, pues recibe el nombre de Judas Iscariote, traidor de Cristo. Estas almas están totalmente enterradas en el hielo. Lucifer es el guardián de toda esta zona y se le representa como un gigante monstruoso que bate sus alas produciendo enormes corrientes de aire que hacen insoportable la estancia de los pecadores en este lugar. En la imagen, Gustave Doré representa a la perfección este espacio frío y lúgubre donde se observan almas cobijadas detrás de las rocas para no sentir el frío provocado por el aleteo de Lucifer. Siempre se ha relacionado el infierno con un lugar relacionado con el fuego, pero Dante lo describió como el lugar más frío del mundo, ya que según su razonamiento, Dios es luz y calor y el infierno es el punto más alejado del paraíso, por lo tanto nunca puede ser cálido. Siguiendo con la descripción, se debe destacar que Lucifer tiene una cabeza con tres caras y en cada boca mastica a los mayores traidores de la historia: Cayo y Marco (traidores de Julio César) y Judas.

Otro elemento de carácter mitológico que ha estado presente en toda la tradición literaria del inframundo e infierno es el conocido Cancerbero, o simplemente Cerbero, capturado por Hades y trasladado al inframundo para custodiar la entrada. De este modo ningún mortal podría acceder y ningún alma podría escapar. La iconografía tradicional lo ha representado con tres cabezas y cola de serpiente. En la Eneida cobra protagonismo cuando la Sibila le lanza una torta amasada con miel y adormidera para aplacarlo: la sabia profetisa viendo que el cuello envedijado de culebras con rabioso ladrido había erizado, échale halagándole delante un gran pedazo de pulposa carne con miel guisado y con terrestres frutos, al cual tenía virtud de infundir sueño (Virgilio, 2000, p. 204).

En La Divina Commedia, encontramos a Cerbero en el tercer círculo del infierno donde moran los condenados por gula. Dante lo describe como un animal horrendo, con ojos encendidos, pelo grasiento con sangre y vientre ancho. Además de emitir unos característicos ladridos, también destaca de él que despedaza las almas con uñas y dientes.

El conocido rey de Creta, Minos, también es un personaje común en ambas obras. Se decía de él que era un justo rey y posiblemente por ello, a su muerte, se convirtió en uno de los tres grandes jueces infernales junto a Radamantis y Éaco, pero era Minos quien tomaba la última decisión. Era el encargado de decidir a qué lugar estaba destinada cada alma: Tártaro o Campos Elíseos. La idea de Minos como juez llegó hasta Dante, y por ello lo colocó en la entrada del segundo círculo donde moran los lujuriosos. Se le describe como un demonio y lo reviste con características terroríficas y grotescas. Virgilio dice de él en la Commedia que cuando el alma mal nacida llega ante él, de todo se confiesa (Alighieri, 2013, p. 109). Tras haber escuchado los pecados de cada alma enrolla su cola tantas veces como al círculo del infierno al que le corresponda ir, tal y como se aprecia de nuevo en la ilustración de Gustave Doré (Figura 3). 


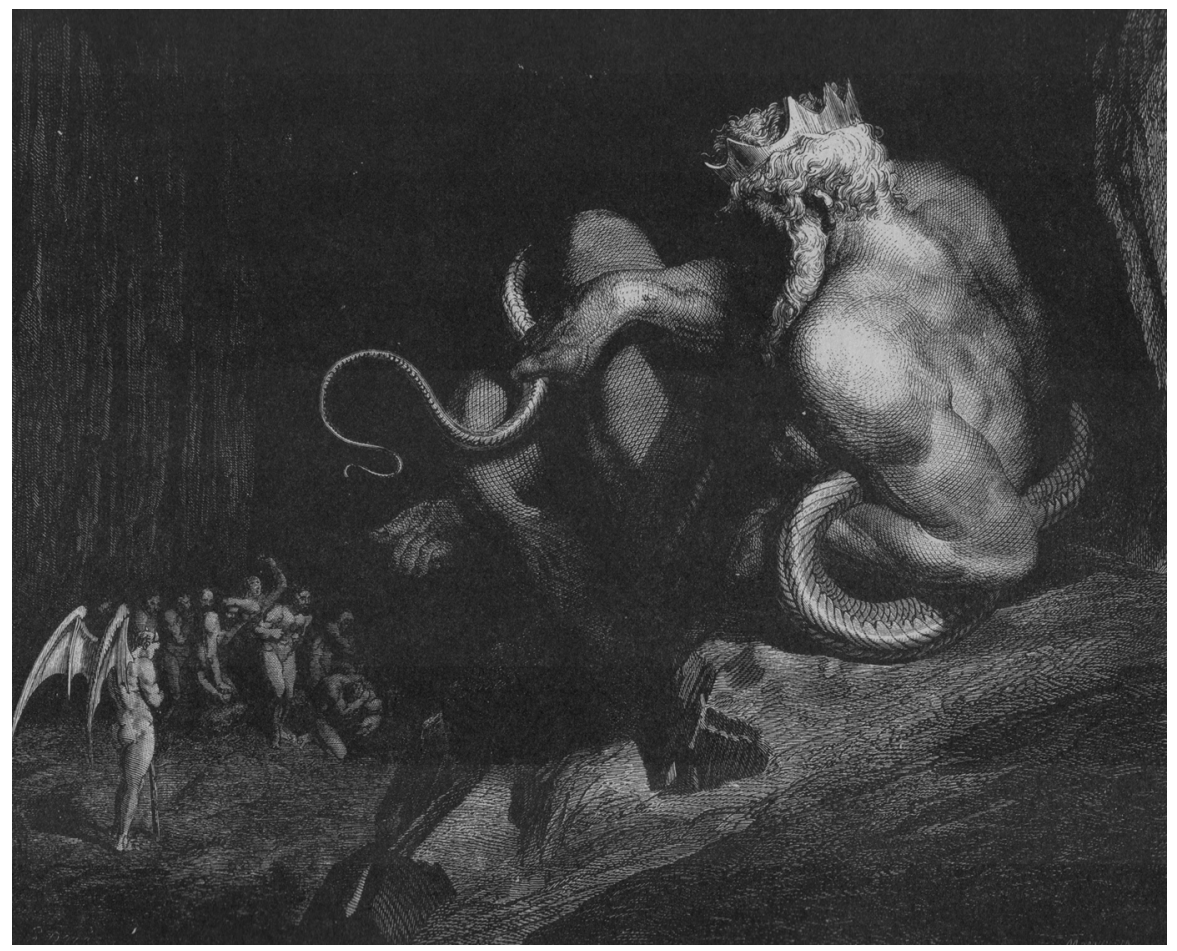

Figura 3. Infierno, canto V, Minos. Gustave Doré. 1832.

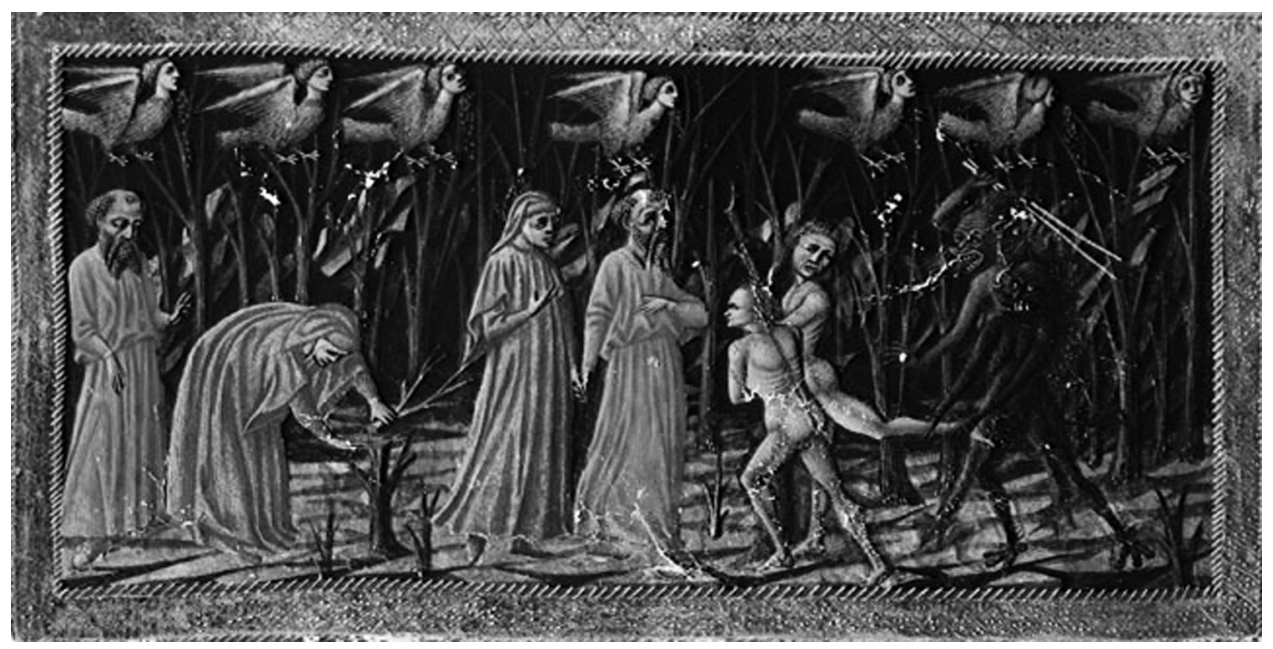

Figura 4. El bosque de los suicidas, Códice Yates Thompson, 36. Priamo della Quercia. 1444-1452. Imagen obtenida de http://www.worldofdante.org/ consultada el día 10 de junio de 2014. 
Continuando con la comparativa entre las similitudes de ambas obras, llega el turno de hablar de la zona reservada a los suicidas. En la Eneida, el espacio que les corresponde está muy cerca de Minos, allí los homicidas contra sí mismos permanecen encadenados para siempre. Los suicidas de La Divina Commedia, sin embargo, tienen un lugar concreto en el séptimo círculo, más específicamente en la segunda vuelta, donde moran los violentos contra sí mismos. Los suicidas han sido convertidos en troncos de madera en los que anidan las Harpías. Virgilio, ante la insistencia de Dante, le explica cómo sucede este fenómeno. Cuando las personas se quitan la vida, el alma va a parar de manera inmediata al séptimo círculo donde nacen en formar de arbustos y árboles. En la imagen se observa claramente cómo las Harpías sobrevuelan los árboles devorados. Dante impresionado ante este hecho parte una rama de un árbol y observa que brota sangre y no resina de él (Figura 4). Recordemos que el suicidio en el Cristianismo es uno de los peores pecados, con lo cual Dante sitúa el "bosque de los suicidas" en un lugar muy cercano a Lucifer.

En la Eneida, muy cerca de los suicidas encontramos el llamado "Valle de los lamentos" donde moran aquellas almas que murieron por amor. Dichas almas están cercadas y cubiertas por mirtos, una planta que en el mundo clásico estaba relacionada con el amor al estar consagrada a la diosa Venus. Además de ello, los difuntos que moran en esta zona mantendrán por siempre el ansia amorosa que les llevó a la muerte. La reina Dido, es protagonista de dicho grupo. No hay que olvidar que fue reina de Cartago y que mantuvo una relación con Eneas, pero a causa de su abandono se quitó la vida. No es coincidencia que en La Divina Commedia Dido se encuentre en el segundo círculo del infierno, donde están situados los lujuriosos. En este caso no están cubiertos con flores, sino que están inmersos en un remolino de viento que no cesa. Este canto es muy conocido por el célebre pasaje de Paolo y Francesca.

En la Eneida, tras el "Campo de los lamentos", Eneas y la Sibila encuentran un cruce de dos caminos: por un lado se va al Tártaro y por el otro a los Campos Elíseos. En el Tártaro moran los delincuentes y los inmorales en vida. Eneas se estremece al escuchar los gritos de dolor que sufren los condenados. Según nos describe Virgilio, el Tártaro es un lugar protegido por una triple muralla circundada por el río de llamas Flegetonte. Todo ello está coronado por una torre de hierro donde habitan las Erinias. La Hidra guarda la puerta para que ningún alma pueda escapar. La Sibila cuenta a Eneas que en el patio interior del Tártaro hay un pozo tan hondo como la distancia entre la Tierra y el Olimpo multiplicado por dos. Ahí residen los Titanes. El Tártaro sería, por lo tanto, el lugar donde los condenados sufrirían los peores castigos. Se podría decir que se corresponde con el infierno cristiano. El viaje de Eneas finaliza en los Campos Elíseos donde se encuentra su padre Anquises.

En La Divina Commedia deberemos de esperar un poco hasta alcanzar lo más parecido a este lugar de paz, el paraíso, que se encuentra totalmente apartado del infierno y en lo alto del purgatorio. Con todo ello es evidente la relación existente entre la Eneida y La Divina Comedia. Dante creó un universo infernal poblado tanto por almas paganas y cristianas que englobaban a héroes y seres mitológicos junto con personajes históricos; todo ello con una esencia virgiliana patente en toda la obra. 


\section{BIBLIOGRAFÍA}

ALIGHIERI, D. (2003): Divina Comedia, Barcelona, Océano, 534 p.

ALIGHIERI, D. (2008): Divina Commedia, Bolonia, Zanichelli, 671 p.

ALIGHIERI, D. (2013): Divina Comedia, Madrid, Cátedra, 790 p.

ANÓNIMO (1997): Poema de Gilgamesh, Madrid, Tecnos, 185 p.

APOLODORO (2004): Biblioteca mitológica, Madrid, Alianza Editorial, 311 p.

BIBLIA (1972): Madrid, Editorial Católica, 1523 p.

BIGI, E. (1981): Forme e significati nella Divina Commedia, Bolonia, Cappelli, 218 p.

BOSCO, U. (1984): Enciclopedia dantesca, Roma, Instituto de la Enciclopedia.

CHIAVACCI LEONARDI, A.M. (1979): La guerra de la pietate. Saggio per una interpretazione dell'Inferno di Dante, Nápoles, Liguori, 215 p.

CRISTÓBAL, V. (2006): "La Eneida de Virgilio, un viaje entre Troya y Roma", Revista de Filología Románica 4, Madrid, Universidad Complutense, 85-100.

DARTMOUTH DANTE PROJECT: http://dante.dartmouth.edu/

GÓMEZ, M. (2009-2010): "La representación del Infierno Devorador en la miniatura medieval", Memorabilia 12, Buenos Aires, 269-287.

GONZÁLEZ, I., BENAVENT, J. (2007): Guía a la lectura de la Divina Comedia, Valencia, Institución Alfons el Magnànim, 553 p.

GONZÁLEZ, J. (1976): La imagen en la poesía de Virgilio: su función, estudio estilístico y literario: resumen de tesis doctoral, Granada, Universidad de Granada, $53 \mathrm{p}$.

GRIMAL, P. (1981): Diccionario de mitología griega y romana, Barcelona, Paidós, 634 p.

HERNÁNDEZ, V.E. (1974): Virgilio, figuras y situaciones de la Eneida: introducción, texto, notas y estudio estilístico, Madrid, G. del Toro, 388 p.

HOMERO (2003): Ilíada, Barcelona, Biblioteca Gredos, 584 p.

HOMERO (2004): Odisea, Madrid, Alianza Editorial, 502 p.

HUMBERT, J. (2003): Mitología griega y romana, Barcelona, Editorial Gustavo Gili S.A, 311 p. Italiana, $6 \mathrm{v}$.

MINOIS, G. (1994): Historia de los infiernos, Barcelona, Paidós, 485 p.

MISSERONI DALLA SERRA, A. (1995): "El descenso al Averno en la Eneida de Virgilio", Iter 3, Santiago de Chile, Universidad Metropolitana de Ciencias de la Educación (UMCE), 77-90.

PÉREZ, E. (2007): "La lógica de lo monstruoso en el Infierno de Dante", Culturas Populares Revista Electrónica 5, Alcalá de Henares, Universidad de Alcalá, 39.

VIDAL, C. (2007): "Imágenes del inframundo: las puertas al infierno", Imagen y cultura: la interpretación de las imágenes como historia cultural VI, Actas Congreso Internacional de la Sociedad Española de Emblemática, Gandía, Universitat Internacional de Gandia, 2008, 1497-1506.

VIRGILIO MARÓN, P. (2000): La Eneida, Barcelona, Planeta, 466.

XELLA, P. (1994): Arqueología del infierno: el más allá en el mundo antiguo Próximo-Oriental y Clásico, Barcelona, Ausa, 270 p. 